\title{
Clostridium difficile Toxin B Is More Potent than Toxin A in Damaging Human Colonic Epithelium In Vitro
}

\author{
Martin Riegler, Roland Sedivy, ${ }^{*}$ Charalabos Pothoulakis, ${ }^{\circ}$ Gerhard Hamilton, Johannes Zacherl, Georg Bischof, \\ Enrico Cosentini, Wolfgang Feil, ${ }^{5}$ Rudolf Schiessel, ${ }^{\mathbf{5}} \mathrm{J}$. Thomas LaMont, ${ }^{\ddagger}$ and Etienne Wenzl \\ University Clinic of Surgery, Vienna; *Institute of Clinical Pathology, University of Vienna; ${ }^{8}$ Surgical Department of Surgery, \\ Danube Hospital, Vienna, Austria; and ${ }^{\ddagger}$ Section of Gastroenterology, The University Hospital, Boston University School of Medicine, \\ Boston, Massachusetts 02118
}

\begin{abstract}
Toxin A but not toxin B, appears to mediate intestinal damage in animal models of Clostridium difficile enteritis. The purpose of this study was to investigate the electrophysiologic and morphologic effects of purified $C$. difficile toxins $A$ and $B$ on human colonic mucosa in Ussing chambers. Luminal exposure of tissues to 16-65 $\mathrm{nM}$ of toxin $A$ and 0.2-29 $\mathrm{nM}$ of toxin $B$ for $5 \mathrm{~h}$ caused dose-dependent epithelial damage. Potential difference, short-circuit current and resistance decreased by 76,58 , and $46 \%$, respectively, with $32 \mathrm{nM}$ of toxin $A$ and by 76,55 , and $47 \%$, respectively, with $3 \mathrm{nM}$ of toxin $\mathrm{B}$, when compared with baseline $(P<0.05)$. $3 \mathrm{nM}$ of toxin A did not cause electrophysiologic changes. Permeability to $\left[{ }^{3} \mathrm{H}\right]$ mannitol increased 16-fold after exposure to $32 \mathrm{nM}$ of toxin $\mathrm{A}$ and to $3 \mathrm{nM}$ of toxin $B$ when compared with controls $(P<0.05)$. Light and scanning electron microscopy after exposure to either toxin revealed patchy damage and exfoliation of superficial epithelial cells, while crypt epithelium remained intact. Fluorescent microscopy of phalloidin-stained sections showed that both toxins caused disruption and condensation of cellular F-actin. Our results demonstrate that the human colon is $\sim 10$ times more sensitive to the damaging effects of toxin $B$ than toxin A, suggesting that toxin $B$ may be more important than toxin $A$ in the pathogenesis of $C$. difficile colitis in man. $(J$. Clin. Invest. 1995. 95:2004-2011.) Key words: $C$. difficile toxins $\bullet$ toxin-mediated enteritis $\bullet$ actin filaments $\bullet$ transepithelial resistance $\cdot$ antibiotic-associated colitis
\end{abstract}

\section{Introduction}

Clostridium difficile, the causative agent of antibiotic-associated colitis in animals $(1,2)$ and humans $(3,4)$, releases two high molecular weight exotoxins: toxin $A$ and toxin $\mathrm{B}(5,6)$. Although numerous animal studies have shown that $C$. difficile colitis is toxin-mediated, the exact role of toxin A and B in pathogenesis, especially in humans, remains unclear. Both toxins possess cytotoxic activity against a variety of cultured cells (6-9) and cause death when injected parenterally in laboratory

Address correspondence to Dr. Etienne Wenzl, University Clinic of Surgery, Währinger Gürtel 18-20, 1090 Vienna, Austria. Phone: 1 40400/5621; FAX: 1 40400/6806.

Received for publication 23 February 1994 and in revised form 25 January 1995.

J. Clin. Invest.

(C) The American Society for Clinical Investigation, Inc.

0021-9738/95/05/2004/08 $\$ 2.00$

Volume 95, May 1995, 2004-2011 animals (10). However, experiments in rabbits $(11,12)$, rats (13), mice (14), and hamsters (15) suggest that only toxin A is capable of damaging the intestinal mucosa in vivo. For example, previous in vivo studies demonstrated that toxin $\mathrm{A}$, but not toxin B, caused severe inflammation, epithelial damage and fluid secretion when injected into rabbit ileal loops in vivo $(11,12)$. Mitchell et al. showed that toxin A caused epithelial damage in rabbit colon, while toxin B had no effect (11). Lyerly et al. also reported that intragastric administration of toxin $\mathrm{A}$, but not toxin B, to hamsters and mice caused hemorrhagic secretion in the small intestine unless the bowel was first damaged before toxin B exposure (15). Moreover, hamsters immunized against toxin B alone were not protected from clindamycin colitis, whereas animals immunized against toxin $\mathrm{A}$, or a combination of toxins A and B were protected (16). Taken together, these results indicate that toxin A causes intestinal damage in animal models, while toxin B is innocuous when placed in the lumen.

While lacking an enterotoxic effect in experimental animals, toxin B is extremely cytotoxic to cultured mammalian cells (6, 17 ), including those derived from the human intestine (19). Recently Hecht et al. demonstrated, that toxin B (19), like toxin A (20), perturbs the cytoskeleton of human colonic cancer T84 cell monolayers causing an increase in permeability and a decrease in transepithelial resistance. However, the possibility remains that the T84 cell-line derived from a colonic adenocarcinoma does not accurately reflect the response of the normal human colon to toxin B.

The purpose of this study was to compare the effects of highly purified toxins $\mathbf{A}$ and $\mathrm{B}$ on human colonic mucosa mounted in Ussing chambers. We report here that toxins $A$ and B disrupt the epithelial barrier and cause epithelial cell necrosis and electrophysiologic changes of the human colon in vitro, but that toxin $B$ is more effective than toxin $A$ in producing these effects.

\section{Methods}

Toxin preparation. Toxins A and B were purified to homogeneity as previously described $(6,21)$. Enterotoxic activity of toxin $A$ was assayed in rat ileal loops (22-24) and cytotoxic activity of both toxins was tested against IMR-90 fibroblasts as previously $(6,21)$. Purity of toxins A and B were determined by SDS-PAGE $(6,21)$. Molar concentrations of toxins $A$ and $B$ were based on molecular weights of $308 \mathrm{kD}$ for toxin A (25) and $279 \mathrm{kD}$ for toxin B (26).

Experimental design. Human colonic mucosal sheets were first equilibrated in Ussing chamber with buffer alone for $60 \mathrm{~min}$. Luminal solution was then replaced with buffer containing 16-65 $\mathrm{nM}$ of toxin A, or $0.2-29 \mathrm{nM}$ of toxin B for $5 \mathrm{~h}$. Control tissues were incubated for $5 \mathrm{~h}$ in buffer only. In an additional series, colonic explants from a single individual were paired and exposed to buffer alone, $3 \mathrm{nM}$ of toxin $\mathrm{A}$ and $3 \mathrm{nM}$ of toxin $\mathrm{B}$, respectively, for $5 \mathrm{~h}(n=4$, paired tissues).

Ussing chamber measurements. Colonic mucosae were obtained from patients who underwent surgery for colorectal cancer. In this study 
a total of 50 individual specimens of histologic tumor-free sigmoid colon was used. After removal of the seromuscular layer by blunt dissection 1 5 mucosal sheets from each specimen measuring 4-10 $\mathrm{cm}^{2}$ were mounted horizontally in custom-made incubation chambers with the luminal surface $\left(1 \mathrm{~cm}^{2}\right.$ surface area) facing upwards as previously described (27). Luminal and serosal side were bathed at $37^{\circ} \mathrm{C}$ with a nutrient buffer containing (mM/liter): $122.0 \mathrm{NaCl}, 2.0 \mathrm{CaCl}_{2}, 1.3$ $\mathrm{MgSO}_{4}, 5.0 \mathrm{KCl}, 20.0$ glucose, $25.0 \mathrm{NaHCO}_{3}(\mathrm{pH}=7.51$ when gassed with $95 \% \mathrm{O}_{2} / 5 \% \mathrm{CO}_{2}$; temperature $37^{\circ} \mathrm{C}$ ). The upper level of fluids in both luminal and serosal reservoirs was identical. Potential difference (PD) ${ }^{1}$ and short-circuit current (Isc) were continuously recorded every $10 \mathrm{~min}$. Luminal and serosal solutions were connected via $\mathrm{Ag}-\mathrm{AgCl}$ electrodes and Ringer-agar bridges to a voltmeter (Model DVC-1000 Voltage/Current Clamp; World Precision Instruments, Inc., New Haven, $C T)$. Resistance (R) was calculated using Ohm's law from the opencircuit PD and the Isc. PD values were given in $\mathrm{mV}$, Isc in $\mu \mathrm{A} / \mathrm{cm}^{2}$, and $\mathrm{R}$ in $\mathrm{Ohm} . \mathrm{cm}^{2}$. PD values were corrected for the junction potentials $(<0.1 \mathrm{mV})$ between the luminal and serosal solutions.

Epithelial permeability to $\left[{ }^{3} \mathrm{H}\right]$ mannitol was determined under short circuit conditions. After an equilibration period of $60 \mathrm{~min}\left[{ }^{3} \mathrm{H}\right]$ mannitol (26.4 Ci/mmol; Dupont-NEN, Boston, MA) was added to the serosal side at a final concentration of $0.32 \mathrm{nM}$. After toxin exposure, luminal aliquots of $100 \mu \mathrm{l}$ were taken for liquid scintillation-counting using 5 $\mathrm{ml}$ of "Quicksafe A" scintillation fluid (Zinsser, Maidenhead, UK). The radioactivity of $\left[{ }^{3} \mathrm{H}\right]$ mannitol in the luminal fluid was measured in counts per minute (cpm) and was assessed at 1,3 , and $5 \mathrm{~h}$ in the presence or absence of 16 and $32 \mathrm{nM}$ of toxin $A$ or 1.5 and $3 \mathrm{nM}$ of toxin $\mathrm{B}$ in the luminal chamber.

Morphometry. After Ussing chamber experiments tissues were processed for light microscopy. Mucosal damage was assessed by an histopathologist (R. Sedivy), who performed morphometry on coded, paraffin embedded, H\&E stained slides as previously described (27), and was "blinded" as to the experimental conditions to which a particular tissue had been exposed. The surface area of each tissue mounted into chambers was $1 \times 1 \mathrm{~cm}$. Morphometry was performed on nine vertical sections from different locations each of which representing the total height and length $(1 \mathrm{~cm})$ of the mucosal preparation. Thus a total length of $\mathbf{8}-\mathbf{9} \mathrm{cm}$ of mucosal surface was examined for each tissue. We used a Leitz Diaplan research microscope (Wild Leitz Ltd, Heerbrugg, Switzerland; objective magnification, $\times 4, \times 6.3, \times 16, \times 25, \times 40$; ocular magnification, $\times 12.5$ ), a Panasonic color CCD video camera (model WV-CD 130/G; Matshushita Com. Ind. Co. Ltd., Japan) an analog/ digital monitor screen (model PVM-1271Q, superfine pitch; Sony, Japan), a personal computer (IBM-PS/2, model PS2; IBM, Armonk, NY), extended by insertion of a frame grabber (ITI PCVision plus board; Imaging Technology Corp., Woburn, MA) and a graphic tablet (Summasketch plus 12" × 12" MM 1201; Summagraphics Corp., Fairfield, CT). Downloading "MIPSY" (The Micro-based Image Processing System ${ }^{\circledast}$ ) on the personal computer, real-time morphometry was performed. The extent of epithelial damage was measured in micrometers and expressed as percent $(\%)$ of total mucosal surface.

Histological criteria for epithelial. damage were: reduced staining intensity of epithelial cells, karyopyknosis, karyolysis and karyorrhexis, cell disruption, formation of subepithelial blebs and lifting off of cells from the basal lamina (27).

Fluorescent microscopy. Fluorescent staining of $\mathrm{F}$ actin was performed using rhodamine-labeled phalloidin (Molecular Probes, Inc., Eugene, OR) on fresh-frozen tissue. Sections $(4 \mu \mathrm{m})$ were fixed in $4 \%$ paraformaldehyde ( $\mathrm{pH} 8.0$ ), washed in phosphate buffered saline solution ( $\mathrm{pH} 8.0$; PBS) and incubated for $45 \mathrm{~min}$. Subsequently, slides were mounted with Glycerol:PBS/1:9 and examined and photographed using a Zeiss Axiophot fluorescence microscope.

Processing for scanning electron microscopy (SEM). Tissues were washed in $0.1 \mathrm{M}$ cacodylate buffer $\mathrm{pH} 7.3$ and postfixed for $90 \mathrm{~min}$ in the same buffer containing $1.0 \%$ buffered osmium tetroxide. Samples

1. Abbreviations used in this paper: Isc, short circuit current; PD, potential difference; $R$, resistance.

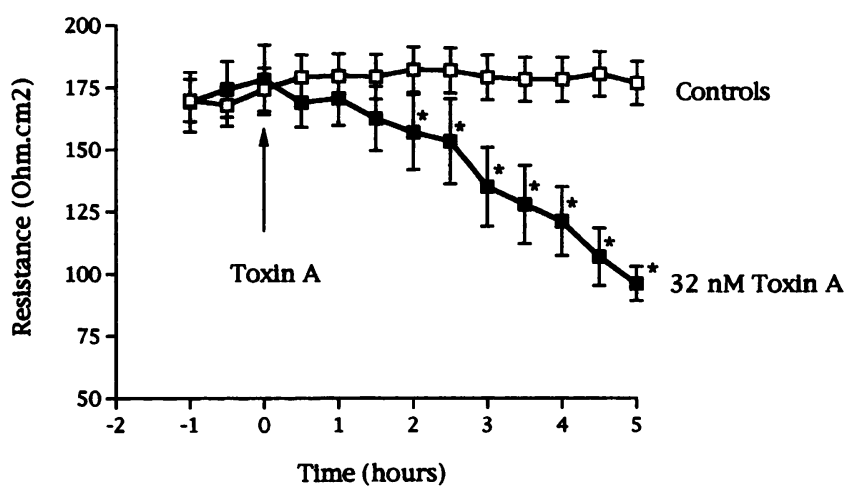

Figure 1. Time course of toxin A on colonic resistance. Human colonic mucosal sheets were incubated continuously with either buffer alone (control) or toxin A for $5 \mathrm{~h}$ ( $n=6$ per group). Values represent mean \pm SEM per group. $\left({ }^{*} P<0.05\right.$, when compared with controls $)$.

were washed again in the buffer and dehydrated in graded series of ethanol. Samples were dried by means of the critical point method (Polaron) and coated with gold up to a thickness of $400 \mathrm{~A}$ in a sputter coating unit (Hummer Jr. Technics). Observations were performed in a Jeol JSM-35CF SEM.

Statistics. All data were expressed as mean \pm SEM and probabilities were regarded as significant if they reached a $95 \%$ level of confidence $(P$ $<0.05)$. Statistical analyses were performed by the test for independent samples by Mann and Whitney using the exact permutational significance levels. The statistical test compared the baseline values for morphometric changes, PD, Isc and $R$ to the values obtained $5 \mathrm{~h}$ after exposure to toxins $A$ and $B$; the values obtained from permeability studies after 1,3 , and $5 \mathrm{~h}$ of toxin exposure were also compared by the same test. For paired observations we performed the test for paired samples by Mann and Whitney comparing the electrophysiological values of $3 \mathrm{nM}$ of toxin A or B to controls.

\section{Results}

Toxin effects on electrophysiology. The effects of toxins A and B on colonic electrophysiology were compared using potential difference (PD), short-circuit current (Isc), and electrical resistance $(R)$. Both toxins caused a time-dependent decrease of electrophysiologic parameters. The time course effect of $32 \mathrm{nM}$ of toxin $A$ is shown in Fig. 1. Luminal toxin exposure caused a rapid decline of resistance that became statistically significant after $2 \mathrm{~h}$ of toxin exposure $(P<0.05)$, and continued to decline until the end of the 5 -h observation period $(n=6)$. A similar progressive decline of resistance was observed in tissues exposed to $16 \mathrm{nM}$ of toxin $\mathrm{A}$, which became significantly different from controls $3 \mathrm{~h}(P<0.05)$ after toxin administration (data not shown).

We next compared the effects of different doses of toxins A and B on electrophysiological parameters. As shown in Table I, PD, Isc and R remained stable for up to $5 \mathrm{~h}$ in the control strips incubated with buffer alone. In contrast, luminal exposure of mucosal strips to 65,32 , and $16 \mathrm{nM}$ of toxin $\mathrm{A}$ or 15,3 , and $1.5 \mathrm{nM}$ of toxin $\mathrm{B}$ for $5 \mathrm{~h}$ caused a significant dose-dependent decrease in all parameters tested as compared to baseline values. For each data set, we compared the effects of toxins to the baseline value for the same colonic strip derived prior to addition of toxins. As shown in Table I, considerable variability in baseline values for all parameters was observed in tissues from different patients. Toxin B was $\sim 10$ times more potent than toxin $\mathbf{A}$ on a molar basis in producing a comparable drop in resistance (Table I, Fig. 2). 
Table I. Effect of Various Concentrations of C. difficile Toxins A and B on Electrophysiology of Human Colonic Mucosa

\begin{tabular}{|c|c|c|c|c|c|c|c|}
\hline & \multicolumn{4}{|c|}{ Toxin A } & \multicolumn{3}{|c|}{ Toxin B } \\
\hline & $\begin{array}{l}\text { Control } \\
(n=6)\end{array}$ & $\begin{array}{c}65 \mathrm{nM} \\
(n=3)\end{array}$ & $\begin{array}{c}32 \mathrm{nM} \\
(n=6)\end{array}$ & $\begin{array}{c}16 \mathrm{nM} \\
(n=4)\end{array}$ & $\begin{array}{c}15 \mathrm{nM} \\
(n=3)\end{array}$ & $\begin{array}{c}3 \mathrm{nM} \\
(n=5)\end{array}$ & $\begin{array}{l}1.5 \mathrm{nM} \\
(n=6)\end{array}$ \\
\hline \multicolumn{8}{|c|}{ PD (mV) } \\
\hline BL & $-22.7 \pm 3.4$ & $-24.5 \pm 4.5$ & $-27.3 \pm 2.8$ & $-23.5 \pm 5.3$ & $-38.4 \pm 13.6$ & $-28.5 \pm 3.5$ & $-22.7 \pm 2.6$ \\
\hline $5 \mathrm{~h}$ & $-22.3 \pm 2.6$ & $-4.7 \pm 1.9 *$ & $-6.4 \pm 1.4^{*}$ & $-6.3 \pm 3.8^{*}$ & $-2.6 \pm 1.1^{*}$ & $-5.3 \pm 0.9 *$ & $-5.5 \pm 1.5^{*}$ \\
\hline \multicolumn{8}{|c|}{ Isc $\left(\mu \mathrm{A} / \mathrm{cm}^{2}\right)$} \\
\hline BL & $129.3 \pm 16.2$ & $126.2 \pm 16.9$ & $152.0 \pm 15.0$ & $153 \pm 18.3$ & $166 \pm 19.0$ & $157.6 \pm 18.6$ & $126.8 \pm 9.2$ \\
\hline $5 \mathrm{~h}$ & $124.8 \pm 8.5$ & $58.0 \pm 8.0^{*}$ & $63.2 \pm 1.0^{*}$ & $54 \pm 13.6 *$ & $42.5 \pm 10.2^{*}$ & $59.2 \pm 7.5^{*}$ & $56.6 \pm 9.9 *$ \\
\hline \multicolumn{8}{|c|}{$\mathrm{R}\left(\Omega \cdot \mathrm{cm}^{2}\right)$} \\
\hline BL & $174.2 \pm 12.6$ & $216.8 \pm 9.7$ & $178.2 \pm 14.0$ & $156.5 \pm 3.7$ & $225 \pm 16.3$ & $180.4 \pm 5.1$ & $179.4 \pm 12.5$ \\
\hline $5 \mathrm{~h}$ & $176.7 \pm 11.4$ & $81.3 \pm 12.8^{*}$ & $96.0 \pm 7.0^{*}$ & $98.5 \pm 8.1^{*}$ & $56 \pm 13.0^{*}$ & $86.4 \pm 6.8 *$ & $94.0 \pm 11.3^{*}$ \\
\hline
\end{tabular}

Mucosal sheets were incubated in Ussing chambers in luminal presence or absence (controls) of various concentrations of toxins A and B for $5 \mathrm{~h}$. Values are mean \pm SEM. $B L$, baseline, $5 h$, after $5 \mathrm{~h}$. $P D$, potential difference; $I s c$, short-circuit current; $R$, resistance. $\left({ }^{*} P<0.05\right.$, when compared to baseline obtained in the same tissue before toxin exposure; $n$ equals the number of experiments using colonic mucosa from separate patients.)

Because, as noted above, tissues from individual patients exhibited considerable variation in baseline electrophysiologic parameters, we carried out experiments where mucosal strips from the same patient were exposed to toxins $A$ and B. As shown in Fig. 3, $3 \mathrm{nM}$ of toxin B caused an immediate decline of resistance, which became statistically significant after $1 \mathrm{~h}(P$ $<0.05$ ), while $3 \mathrm{nM}$ of toxin A failed to show an effect ( $n$ $=4$, paired tissues). Resistance further declined in the $3 \mathrm{nM}$ toxin B group until the end of the experiments (Fig. 3).

Permeability to $\left[{ }^{3} \mathrm{H}\right]$ mannitol. We next investigated the effect of various doses of toxins $A$ and $B$ on serosal to mucosal permeability to $\left[{ }^{3} \mathrm{H}\right]$ mannitol (Fig. 4). A small increase was noted at 3 and $5 \mathrm{~h}$ in control tissues incubated only with buffer. Permeability was increased by 6 - and 11 -fold in tissues exposed to 16 or $32 \mathrm{nM}$ of toxin $A$ or 1.5 or $3 \mathrm{nM}$ of toxin $B$, respectively, after $3 \mathrm{~h}$ of continuous toxin administration. A similar trend in increased $\left[{ }^{3} \mathrm{H}\right]$ mannitol permeability was measured after $5 \mathrm{~h}$ exposure of tissues to the same doses of toxins (Fig.

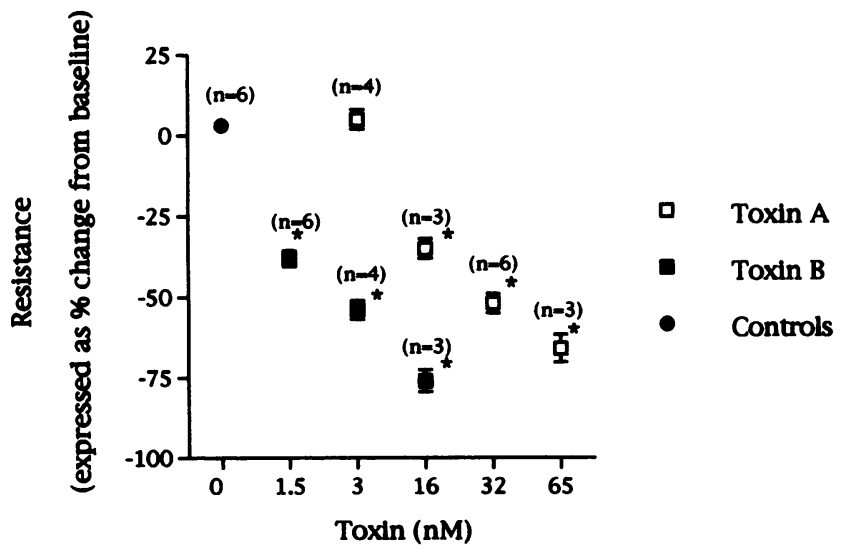

Figure 2. Dose-dependent effect of toxin A and B on colonic resistance. Human colonic tissues were placed in Ussing chambers and incubated with various doses of toxins A or B for $5 \mathrm{~h}$. Resistance was calculated from potential difference and short-circuit current and results are presented as $\%$ change from baseline. Values represent mean $\pm \mathrm{SEM}$. The number of experiments is given in brackets. ( ${ }^{*} P<0.05$ vs. controls).
4). Thus toxin $B$ elicited an equivalent increase of $\left[{ }^{3} \mathrm{H}\right]$ mannitol permeability at a 10 -fold lower dose than toxin $\mathrm{A}$.

Histology. No tissue strips used in these experiments showed histological criteria of malignancy. Histologic examination of colonic strips incubated with buffer alone for $5 \mathrm{~h}$ showed excellent preservation of normal colonic architecture (Fig. $5 A$ ). Toxins $A$ and $B$ exerted similar histologic changes depending on the concentration. The primary effect of both toxins was exerted on superficial epithelial cells whereas the epithelium of the crypts remained intact (Fig. $5 B$, toxin $A, 32 \mathrm{nM}$ and $5 C$, toxin B, $3 \mathrm{nM}$ ). A typical histologic finding was a patchy distribution of the lesions, resulting in appearance of intact epithelium adjacent to severely damaged areas (Fig. $5 \mathrm{D}$ ). After toxin A or toxin B exposure, histologic examination revealed flat epithelial cells with regular staining intensity covering the basal lamina propria in the damaged areas (Fig. $5 \mathrm{D}$, arrow). These colonocytes had flattened nuclei which were oriented parallel to the basal lamina propria (Fig. $5 \mathrm{D}$ ).

Toxin-mediated morphologic damage expressed as the percent of damaged mucosa was dose-dependent (Fig. 6). Again

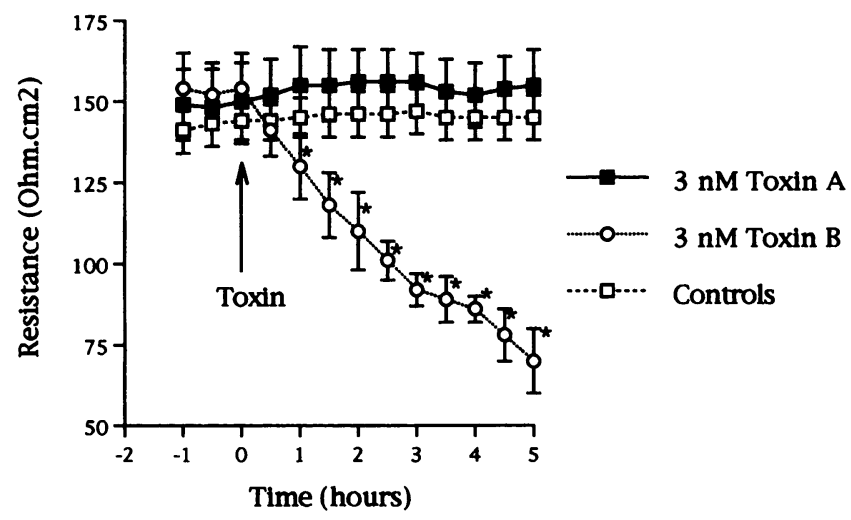

Figure 3. Time course of toxin A and B on resistance of paired colonic tissues. Paired human colonic mucosal sheets were continuously incubated with buffer alone (controls) or $3 \mathrm{nM}$ of toxin A or B for $5 \mathrm{~h}$ ( $n$ $=4$ per group). Values represent mean \pm SEM per group. $\left({ }^{*} P<0.05\right.$, when compared with controls). 


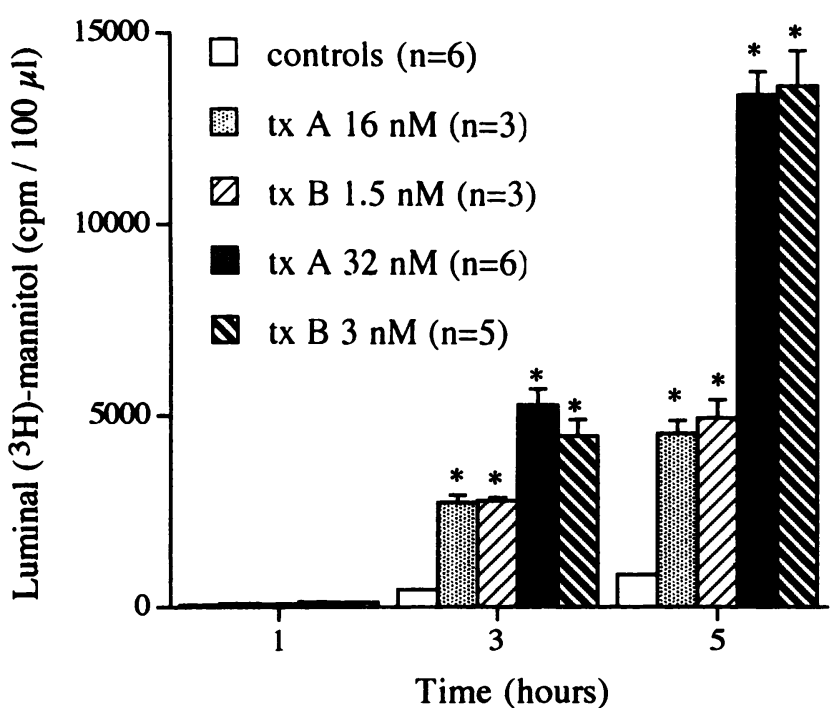

Figure 4. Effect of toxins A and B on colonic $\left[{ }^{3} \mathrm{H}\right]$ mannitol permeability. Human colonic mucosal sheets were incubated with either buffer alone (control), or buffer containing toxin A (tx A) or toxin B (tx B). Toxin B elicited an equivalent increase of luminal $\left[{ }^{3} \mathrm{H}\right]$ mannitol at a 10 -fold lower dose than toxin A. Results are expressed as mean \pm SEM. The number of experiments is given in brackets. Luminal $\left[{ }^{3} \mathrm{H}\right]$ mannitol was determined as described in Methods. ( ${ }^{*} P<0.05$ vs. control). toxin $\mathrm{B}$ was $\sim 8-10$ times more potent than toxin $\mathrm{A}$ on a molar basis. While $3 \mathrm{nM}$ of toxin B caused mucosal damage of $31 \%$, $3 \mathrm{nM}$ of toxin A had no effect (Fig. 6). At the lowest concentration of toxin B used in these studies $(0.2 \mathrm{nM})$ we observed morphologic damage to single cells (Fig. 7, $A$ and $C$ ). At $3 \mathrm{nM}$ of toxin B scanning electron microscopy revealed widespread damage of superficial colonic epithelial cells (Fig. $7 \mathrm{D}$ ).

Distribution of F-Actin. In previous studies we reported that purified toxins $A$ and $B$ caused a marked decrease in fluorescent staining for F-actin in monolayers of the T84 colonic adenocarcinoma cell line $(19,20)$. We therefore assessed the effect of toxins $\mathrm{A}$ and $\mathrm{B}$ on $\mathrm{F}$-actin distribution in human colonic strips. Control cells had a polygonal shape with F-actin distributed in the peripheral actinomyosin ring associated with the cell membrane (Fig. $8 A$ ). In contrast, tissues treated with toxin B for $5 \mathrm{~h}$ showed complete disorganization of the normal F-actin pattern with clumping of actin within cells (Fig. $8 \mathrm{~B}$ ). Similar alterations of intracellular F-actin were seen in tissues treated with toxin A (data not shown).

\section{Discussion}

In this in vitro study we provide evidence that toxins A and B of Clostridium difficile cause dose-dependent electrophysiologic alterations and morphologic damage in human colonic
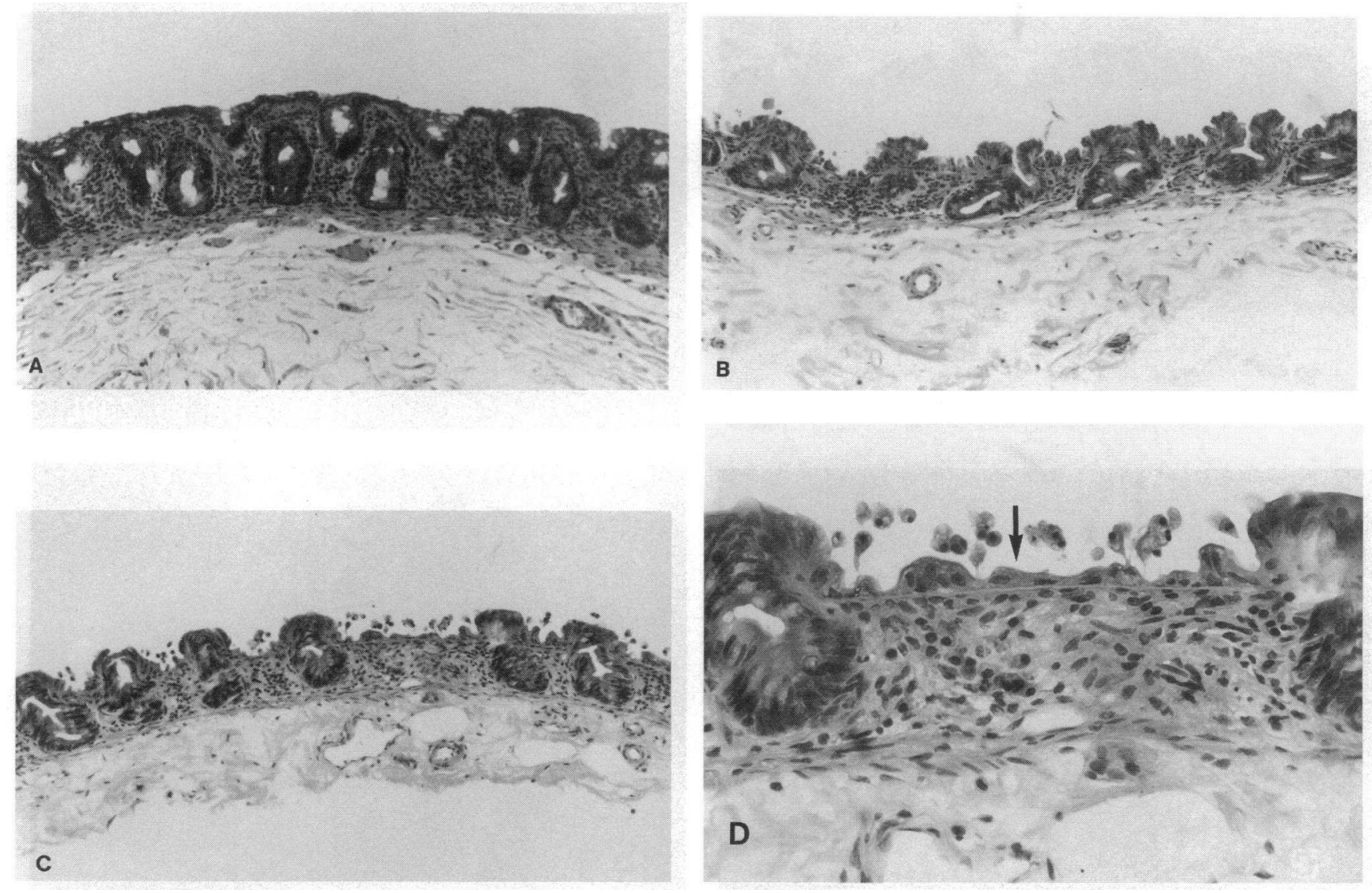

Figure 5. Morphologic effect of toxin A and B on human colonic mucosa. Human colonic mucosal sheets were incubated with either buffer alone $(A)$ or buffer containing $32 \mathrm{nM}$ of toxin $\mathrm{A}(B)$ or $3 \mathrm{nM}$ of toxin $\mathrm{B}(C$ and $D)$ for $5 \mathrm{~h}$. At the end of the incubation period sheets were fixed in formalin and processed for light microscopy. Control tissue $(A)$ appears normal and epithelial cells form a continuous sheet of cells over the lamina propria. In contrast, mucosal sheets exposed to toxin A $(B)$ or B $(C)$ show disruptions of the superficial epithelium whereas the crypt epithelium remains intact. $D$ shows higher magnification of human colonic mucosa exposed to buffer containing $3 \mathrm{nM}$ of toxin B for $5 \mathrm{~h}$. Damaged epithelial cells are rounded up and unattached to the basal lamina whereas viable epithelial cells flatten to reseal the epithelial discontinuity (arrow).

Undamaged epithelium is present at both sides of the damaged area in the center of the slide. $A-C, \times 50$; in $D, \times 200$. 


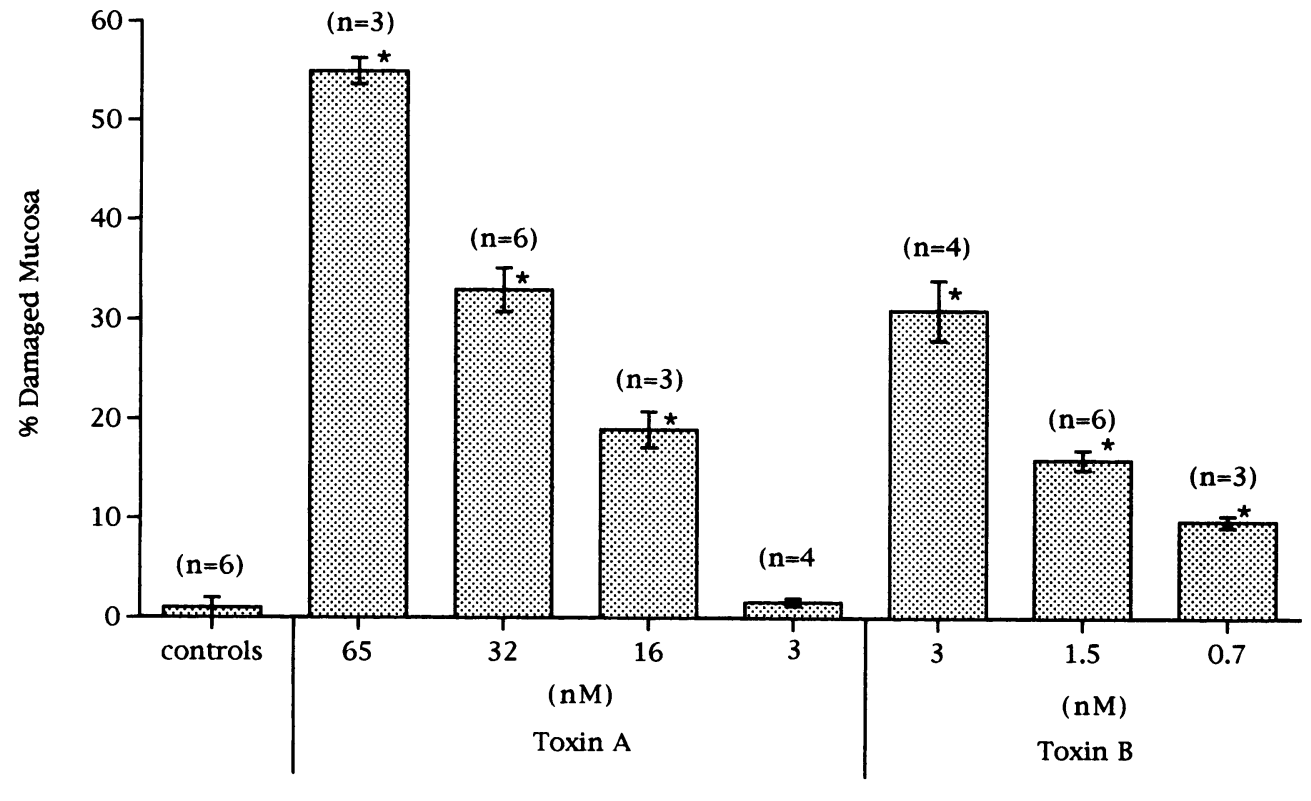

Figure 6. Morphometric analysis of colonic epithelial cell damage by toxins $\mathrm{A}$ and $\mathrm{B}$. Human colonic mucosal sheets were incubated with buffer alone (control) or buffer containing either $65,32,16$, or $3 \mathrm{nM}$ of toxin $\mathrm{A}$ or $3,1.5$, or $0.7 \mathrm{nM}$ of toxin B for $5 \mathrm{~h}$. Mucosal sheets were fixed in formalin, processed for light microscopy and morphometric analysis was performed as described in Methods. Results are presented as mean \pm SEM. The number of experiments is given in brackets. ( ${ }^{*} P<0.05$ vs. controls).
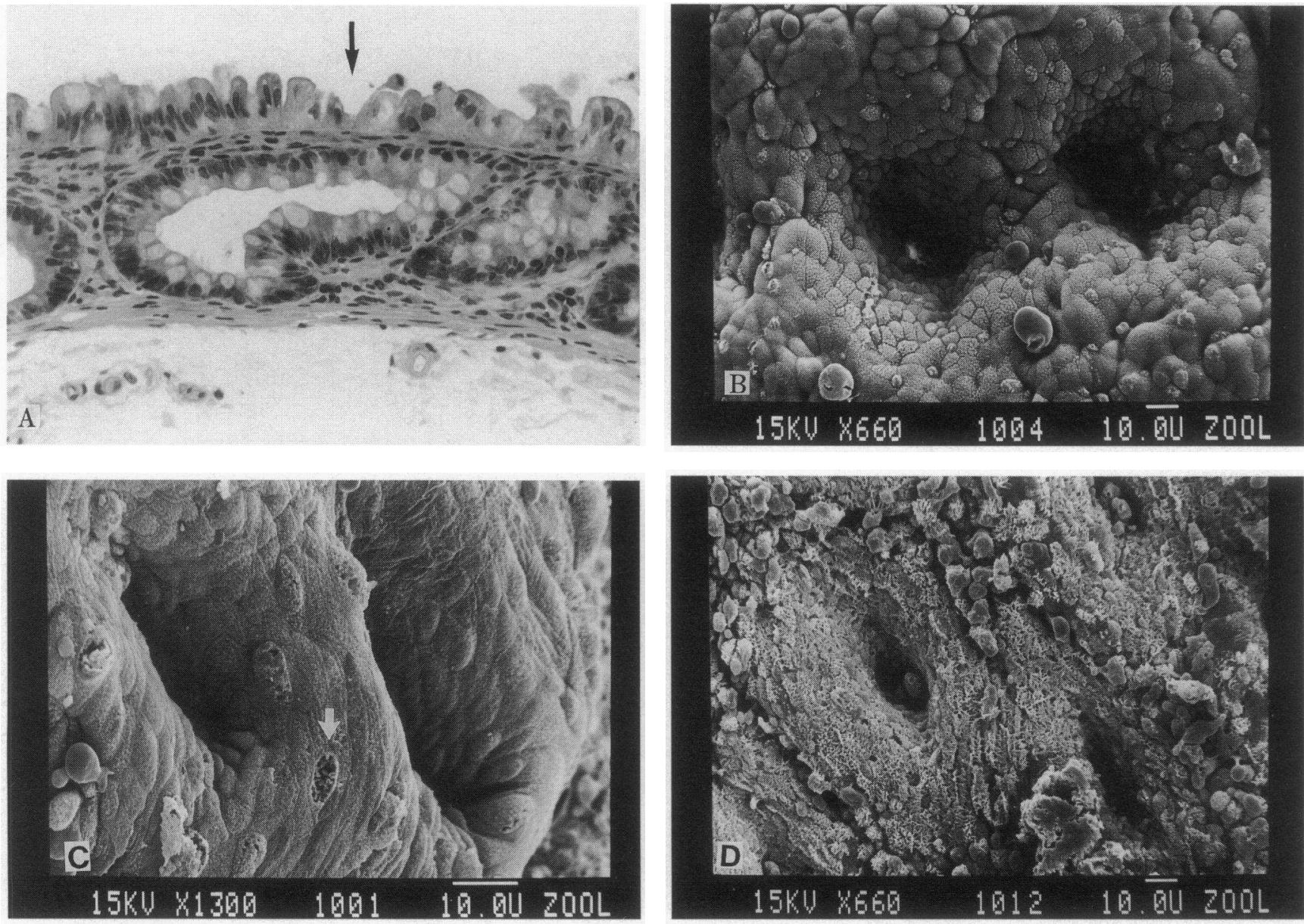

Figure 7. Light $(A)$ and scanning electron microscopy $(B-D)$ of toxin B-exposed human epithelial cells. Human colonic mucosal sheets were placed in Ussing chambers and incubated with either buffer alone $(B)$ or buffer containing $0.2 \mathrm{nM}(A$ and $C)$ or $3 \mathrm{nM}$ of toxin B for $5 \mathrm{~h}(D)$. Mucosa exposed to buffer alone $(B)$ shows regular arrangement of polygonal epithelial cells. Low dose of toxin B causes single cell lesions $(A$ and $C$, arrows $)$. Exposure to higher concentration $(3 \mathrm{nM})$ causes extensive destruction of the surface epithelium $(D)$. Damaged epithelial cells round up and detach into the lumen. $A: \times 200 ; B$ and $D: \times 330 ; C: \times 650$. 


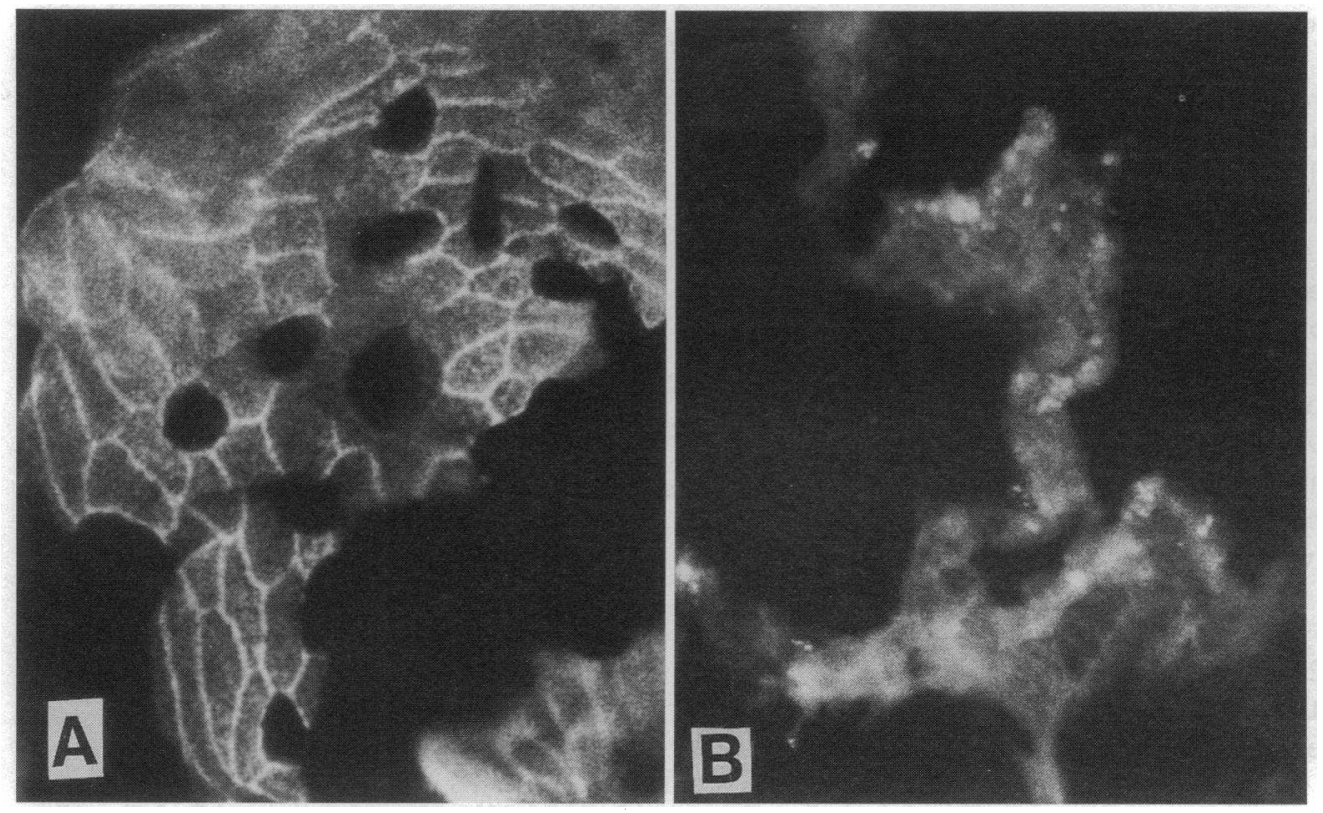

Figure 8. Effect of toxin B on cellular F-actin. Fluorescent photomicrograph of human colonic mucosal sheet incubated with buffer alone $(A)$ or buffer containing 3 $\mathrm{nM}$ of toxin B $(B)$ for $5 \mathrm{~h}$. Samples were then fixed and fresh-frozen sections cut perpendicular to the long axis of surface cells were stained with the $F$ actin specific rhodamine-labeled phalloidin. Note the intracellular condensation of $\mathrm{F}$ actin in toxin $\mathrm{B}$ exposed tissues $(B)$, as opposed to the ring like distribution of $\mathrm{F}$ actin seen in controls $(A) . \times 400$.

strips in Ussing chambers. Toxin exposure caused an immediate decrease of resistance (Figs. 1 and 2) which became statistically significant within $1-3 \mathrm{~h}$ of toxin exposure. This is in contrast to our previous results obtained with T84 cells (19) which showed that a latency period of $1-2 \mathrm{~h}$ occurred between toxin exposure and the onset of an electrophysiologic effect. While toxin A was more potent than toxin B in all previous studies in experimental animals, we report here for the first time that toxin $B$ is $\sim 10$-fold more potent on a molar basis than toxin $\mathrm{A}$ in human mucosa (Table I, Fig. 2). For example, we previously reported that in T84 cells toxin A at a concentra-

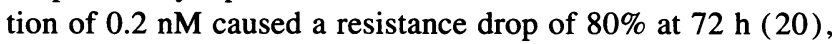
compared with toxin $B$ which caused the same effect at a concentration of $2.5 \mathrm{nM}$ (19). As reported here (Fig. 2) resistance was decreased by $46 \%$ at a toxin A concentration of 32 $\mathrm{nM}$ whereas only $3 \mathrm{nM}$ toxin $\mathrm{B}$ was required to produce a similar decrease (Table I, Fig. 3). These differences in relative sensitivity to toxins probably reflect differences between neoplastic T84 cells vs. normal intestinal strips, as well as methodological differences between cell-lines and tissue strips in a chamber. One limitation of Ussing chamber experiments is that the maximum period of observation is $6 \mathrm{~h}$ after which time necrosis of tissue ensues. For this reason, higher concentrations of toxins are required to produce an effect within a few hours, while in the T 84 cell system continuous observation for 2 or $3 \mathrm{~d}$ are possible, thus allowing lower toxin doses. In these experiments reported here we used concentrations of toxin A or B ranging between 0.2 and $65 \mathrm{nM}$. Similar doses of toxin $A(6-30 \mathrm{nM})$ were required in previous experiments to produce an acute inflammatory and secretory response in rat ileal loops in vivo (12). However, since no detailed studies are available regarding the concentration of either toxin in stools from patients with $C$. difficile colitis, the relationship between our in vitro results and actual $C$. difficile infection in patients remains speculative.

Our previous results $(20)$ on cultured human intestinal T84 cell monolayers indicate that electrical resistance changes in response to toxin $\mathrm{A}$ are a more sensitive indicator of barrier function than mannitol flux. In T84 cells, large changes in sero- sal-to-mucosal fluxes in response to toxin A were observed only after resistance was maximally affected (e.g., 3-4-fold decrease). Similarly in this study, mannitol fluxes were not correlated directly with maximal resistance changes at $5 \mathrm{~h}$. For example, exposure of colonic explants to $32 \mathrm{nM}$ toxin A or 1.5 $\mathrm{nM}$ toxin $\mathrm{B}$ produced an equivalent drop in resistance to 95 $\mathrm{Ohm} \times \mathrm{cm}^{2}$ at $5 \mathrm{~h}$ (Table I). Despite these nearly identical resistance values, mannitol fluxes were nearly threefold higher in the explants exposed to $32 \mathrm{nM}$ toxin A vs. $1.5 \mathrm{nM}$ toxin $\mathrm{B}$. Some of this discrepancy possibly relates to a difference in the time of onset and rate of decline of resistance changes at varying toxin concentrations. Although the final resistance might be identical at $5 \mathrm{~h}$, mannitol fluxes over the entire 5 -h period might vary considerably. However, measurement of mannitol fluxes over consecutive 15 - or 30 -min periods might reveal closer correlation with resistance changes.

In contrast to earlier animal studies where toxin A was reported to cause diffuse mucosal damage $(12,13,23,24)$, we report here that toxins $\mathrm{A}$ and $\mathrm{B}$ cause patchy or even discrete single cell lesions in human colon depending on the toxin concentration. At lower toxin doses epithelial cell damage is patchy, but becomes more confluent at higher doses (Figs. 5-7). This finding may correlate with the variability of colonic pseudomembrane observed in patients with antibiotic-associated colitis secondary to $C$. difficile. In some patients with $C$. difficile colitis pseudomembranes are discrete, while in others the membrane and subjacent inflammatory response may cover the entire mucosal surface. Our in vitro results suggest that the extent of colonic damage is related to the toxin concentrations and the duration of exposure before diagnosis. We observed in our study that both toxins caused damage of superficial epithelial cells while crypt epithelium remained intact (Fig. 5 and 7). This finding could be explained by a different distribution of toxin $A$ and $B$ receptors on mucosal epithelium. For example, we have previously reported that binding of biotinylated toxin $\mathrm{A}$ to rabbit ileum was limited to the brush border of villus tip cells with no binding on the crypt epithelial cells (28). Conceivably, a similar distribution of toxin A or B receptors in superficial vs. crypt colonocytes may explain the absence of damage 
to crypt cells compared with the extensive necrosis observed in superficial epithelial cells.

A possible explanation for the lack of intestinal effects of toxin B in animal models $(11,12,15)$ is absence of receptor binding sites for this toxin in rodent intestine. Previous studies have suggested a strong correlation between presence of membrane receptors for either toxin A or toxin B and biologic responsiveness to these toxins. For example Rolfe (29), using radiolabeled toxin $B$, failed to show any toxin $B$ specific binding sites for this toxin in hamster intestine, a tissue known to be insensitive to toxin B (15). Conversely, hamster and rabbit intestine possess specific toxin $\mathrm{A}$ brush border receptors and both tissues are sensitive to the intestinal effects of toxin A (11, $12,15,29)$. In addition, diminished toxin $A$ receptor binding activity in newborn rabbit ileum was associated with a substantial reduction in biologic effect, while developmental increase in receptor activity from birth to age $24 \mathrm{~d}$ was associated with acquisition of toxin sensitivity (28). Although binding activity was not measured in the present study, our results imply that receptors for both toxins are present in the luminal aspect of colonocytes.

We observed disruption and clumping of actin in colonocytes exposed to toxin B (Fig. 8) similar to changes reported previously by us in guinea pig ileum (30) and in human T 84 colonic cells $(19,20)$. In human fibroblast cell lines the level of filamentous actin declined prior to cell rounding (6). The action of these toxins on filamentous actin in target cells is most likely related to the catalytic action of toxins on Rho A and B, small GTP-binding proteins known to be involved in actin filament assembly (31). The similarity of action of toxins $A$ and $B$ in the human colon is not surprising based on their striking amino acid homology $(25,26)$.

The mechanism by which toxins A and B damage the human intestine can be categorized as direct and indirect. Direct toxicity occurs when cultured cells are exposed to toxins A and B, and presumably occurs via toxin binding, internalization (17) and disruption of the cytoskeleton with eventual inhibition of protein synthesis (18) and cell division. Part of the intestinal effects of toxin A described in ileal loop studies results from indirect activation of lamina propria neuroimmune cells (23, $24,32-35$ ) and infiltration of the ileal submucosa by neutrophils $(23,24,35,36)$. In the experiments reported here we assume that the immediate onset of electrophysiological changes after luminal toxin exposure suggests direct damage, although we can not exclude the release of cytokines, prostanoids or other pro-inflammatory mediators from lamina propria immune cells present in these mucosal strips. Studies are underway to define the possible contribution of epithelial and nonepithelial cells to the toxin effects described here.

\section{Acknowledgments}

The authors thank Dr. Tacettin Sogukoglu, for his expert technical support.

This study was supported by grants from the "Jubiläumsfonds der Österreichischen National bank" and the "Anton Dreher-Gedächtnisschenkung des Medizinischen Dekanats der Universität Wien”, and by research grant DK-34583 from the National Institutes of Health. Dr. Pothoulakis is a recipient of a Research Award from the Crohn's and Colitis Foundation of America.

\section{References}

1. Bartlett, J. G., A. B. Onderdonk, R. L. Cisneros, and D. L. Kasper. 1977. Clindamycin-associated colitis due to a toxin-producing species of Clostridium in hamsters. J. Infect. Dis. 136:701-705.
2. Abrams, G. D., M. Allo, G. D. Rifkin, R. Fekety, and J. Silva, Jr. 1980 Mucosal damage mediated by clostridial toxin in experimental clindamycin-associated colitis. Gut. 21: 493-499.

3. Bartlett, J. G., W. Chang, M. Gurwith, S. L. Gorbach, and A. B. Onderdonk 1978. Antibiotic associated pseudomembranous colitis due to toxin-producing clostridia. N. Engl. J. Med. 298:531-534.

4. Bartlett, J. G., N. Moon, W. Chang, N. Taylor, and A. B. Onderdonk. 1978. Role of Clostridium difficile in antibiotic-associated pseudomembranous colitis. Gastroenterol. 75:778-782.

5. Sullivan, N. M., S. Pellet, and T. D. Wilkins. 1982. Purification and Characterization of toxins A and B of Clostridium difficile. Infect. Immun. 35:10321040.

6. Pothoulakis, C., L. M. Barone, R. Ely., B. Faris, M. E. Clark, C. Franzblau, and J. T. LaMont. 1986. Purification and Properties of Clostridium difficile cytotoxin B. J. Biol. Chem. 261:1316-1321.

7. Donta, S. T., N. Sullivan, and T. D. Wilkins. 1982. Differential effects of Clostridium difficile toxins on tissue-cultured cells. J. Clin. Microbiol. 15:11571158.

8. Wedel, N., P. Toselli, C. Pothoulakis, B. Faris, P. Oliver, C. Franzblau, and J. T. LaMont. 1983. Ultrastructural effects of Clostridium difficile toxin B on smooth muscle cells and fibroblasts. Exp. Cell. Res. 148:413-422.

9. Fiorentini, C., M. Thelestam. 1991. Interaction of cytopathogenic toxin from Clostridium difficile toxin A and it's effect on cells. Toxicon. 29: 543-567.

10. Lyerly, D. M., P. E. Lockwood, S. H. Richardson, and T. D. Wilkins 1985. Biological activities of toxins $\mathrm{A}$ and $\mathrm{B}$ of Clostridium difficile. Infect. Immun. 35:1147-1150.

11. Mitchell, T. J., J. M. Ketley, S. C. Haslam, J. Stephen, D. W. Burdon, D. C. A. Candy, and R. Daniel. 1986. Effect of toxin A and B of Clostridium difficile on rabbit ileum and colon. Gut. 27:78-85.

12. Triadafilopulos, G., C. Pothoulakis, M. O'Brien, and T. J. LaMont. 1987. Differrential effects of Clostridium difficile toxins A and B on rabbit ileum. Gastroenterology. 93: 273-279.

13. Torres, J., E. Jennische, S. Lange, and I. Lönnroth. 1990. Enterotoxins from Clostridium difficile; diarrhogenic potency and morphological effects in the rat intestine. Gut. 31: 781-785.

14. Ehrich, M. 1982. Biochemical and pathological effects of Clostridium difficile toxins in mice. Toxicon. 20: 983-989.

15. Lyerly, D. M., K. E. Saum, D. K. McDonald, T. D. Wilkins. 1985. Effects of $C$. difficile toxins given intragastrically to animals. Infect. Immun. 47:349352.

16. Kim, P. H., F. P. Iaconis, and R. D. Rolfe. 1987. Immunization of adult hamsters against Clostridium difficile -associated ileocecitis and transfer of protection to infant hamsters. Infect. Immun. 55:2984-2992.

17. Thelestam M., and I. Florin. 1984. Cytopathogenic action of Clostridium difficile toxins. J. Toxicol. Toxin Rev. 3:139-180.

18. Pothoulakis C., G. Triadafilopoulos, M. Clark, C. Franzblau, and J. T. LaMont. 1986. Clostridium difficile cytotoxin inhibits protein synthesis in fibroblasts and intestinal mucosa. Gastroenterol. 91:1147-1153.

19. Hecht G., A. Koutsouris, C. Pothoulakis, J. T. LaMont, and J. L. Madara. 1992. Clostridium difficile toxin B disrupts the barrier function of T84 Monolayers. Gastroenterol. 102:416-423.

20. Hecht G., C. Pothoulakis, J. T. LaMont, and J. L. Madara. 1988. Clostridium difficile toxin A perturbs cytoskeletal structure and tight junction permeability of cultured human intestinal epithelial monolayers. J. Clin. Invest. 82:1516-1524.

21. Pothoulakis C., J. T. LaMont, R. Eglow, N. Gao, J. B. Rubins, T. C. Theoharides, and B. F. Dickey. 1991. Characterization of rabbit ileal receptors for Clostridium difficile toxin A. Evidence for a receptor-coupled G protein. $J$. Clin. Invest. 88:119-125.

22. Pothoulakis. C., C. P. Kelly, M. A. Joshi, N. Gao, C. J. O'Keanne, I. Castagliuolo, and J. T. LaMont. 1993. Saccharomyces boulardii inhibits Clostridium difficile toxin A binding and enterotoxicity in rat ileum. Gastroenterology. 104:1108-1115.

23. Pothoulakis, C., F. Karmeli, C. P. Kelly, L. M. Barone, R. Eliakim, M. A Joshi, C. J. O'Keane, I. Castagliuolo, J. T. LaMont, and D. Rachmilewitz. 1993. Ketotifen inhibits Clostridium difficile toxin A-induced enteritis in rat ileum. Gastroenterol. 105:701-707.

24. Pothoulakis C., I. Castagliuolo, J. T. LaMont, A. Jaffer, J. C. O'Keane, R. M. Snider, and S.E. Leeman. 1994. CP-96, 345, a substance P antagonist, inhibits rat intestinal responses to Clostridium difficile toxin A but not cholera toxin. Proc. Natl. Acad. Sci. USA. 91:947-951.

25. Dove, C. H., S. Z. Wang, S. B. Price, D. M. Lyerly, T. D. Wilkins, and J. L. Johnson. 1990. Molecular characterization of the Clostridium difficile toxin A gene. Infect. Immun. 58:480-488.

26. Barroso, L. A., S. Z. Wang, C. J. Phelps, J. L. Johnson, and T. D. Wilkins. 1990. Nucleotide sequence of Clostridium difficile toxin B gene. Nucleic Acid Res. 18:4004.

27. Feil. W., E. Lacy, Y. M. Wong, D. Burger, E. Wenzl, M. Starlinger, and R. Schiessel. 1989. Rapid epithelial restitution of the human and rabbit colonic mucosa. Gastroenterology. 97:685-701.

28. Eglow R., C. Pothoulakis, S. Itzkowitz, E. J. Israel, C. J. O'Keane, D. Dahai, N. Gao, Y.L. Xu, W. A. Walker, and J. T. LaMont. 1992. Diminished 
Clostridium difficile toxin A sensitivity in newborn rabbit is associated with decreased toxin A receptor. J. Clin. Invest. 90:822-829.

29. Rolfe, R. D. 1991. Binding kinetics of Clostridium difficile toxins A and B to intestinal brush border membranes from infant and adult hamsters. Infect. Immun. 59:1223-1230.

30. Moore, R., C. Pothoulakis, J. T. LaMont, S. Carlson, and J. L. Madara. 1990. C. difficile toxin $\mathrm{A}$ increases intestinal permeability and induces $\mathrm{Cl}$ secretion. Am. J. Physiol. 259:G165-G172.

31. Just, I., G. Fritz, M. Giry, M. R. Popoff, P. Boquet, S. Hegenbarth, and C. Von Eichel-Streiber. 1994. Clostridium difficile toxin B acts on the GTPbinding protein Rho. J. Biol. Chem. 269:10706-10712.

32. Miller P. D., C. Pothoulakis, T. R. Baeker, J. T. LaMont, and T. L. Rothestein. 1990. Macrophage-dependent stimulation of T-cell depleted spleen cells by Clostridium difficile toxin $\mathbf{A}$ and calcium ionophore. Cell. Immunol. 126:155-163.
33. Flegel, W. A., F. Müller, W. Daubener, H. G. Fischer, U. Hadding, and H. Northoff. 1991. Cytokine response by human monocytes to Clostridium difficile toxin A and B. Infect. Immun. 59:3659-3666.

34. Castagliuolo, I., C. P. Kelly, C. J. O'Keane, J. T. LaMont, and C. Pothoulakis. 1993. The enteric nervous system participates in the inflammatory response to Clostridium difficile toxin A in rat ileum. Gastroenterology. 104:677a. (Abstr.)

35. Triadafilopoulos, G., C. Pothoulakis, R. Weiss, C. Giampaolo, and J. T. LaMont. 1987. Comparative study of Clostridium difficile toxin A and cholera toxin in rabbit ileum. Role of prostaglandins and leukotrienes. Gastroenterology. 92:1174-1180.

36. Kelly, C. P., S. Becker, J. K. Linevsky, M. A. Joshi, J. C. O'Keane, B. F. Dickley, J. T. LaMont, and C. Pothoulakis. 1994. Neutrophil recruitment in Clostridium difficile toxin A enteritis in the rabbit. J. Clin. Invest. 93:12571265. 